\title{
PERUBAHAN ISTILAH KEKERABATAN DAN HUBUNGANNYA DENGAN SISTEM KEKERABATAN PADA MASYARAKAT MINANGKABAU
}

\author{
Sri Meiyenti, Syahrizal'
}

\begin{abstract}
This article talks about the changes that occur in the Minangkabau kinship. Aspect of concern is about the kinship term system in relate with term of reference and term of address. Kinship term system have consequence in the rights and obligations. Changes in the kinship term system causes changes to the rights and obligations of kinship in the Minangkabau society.
\end{abstract}

Key words: Kinship, Term System of Kinship, Changes, Minangkabau Society

\section{A. Pendahuluan}

S istem kekerabatan mempunyai arti penting dalam banyak masyarakat baik masyarakat sederhana maupun masyarakat yang sudah maju, hubungan dengan nenek moyang dan kerabat adalah kunci hubungan dalam struktur sosial. Hubungan dengan kerabat tersebut menjadi poros dari berbagai interaksi, kewajibankewajiban, loyalitas, dan sentimen-sentimen. Dalam masyarakat di mana loyalitas kekerabatan sangat penting pada kerabat menggantikan loyalitas pada yang lain. Artinya sistem kekerabatan sangat erat kaitannya dengan struktur sosial yang dibangunnya lebih lanjut. Sistem kekerabatan menentukan posisi seseorang dalam masyarakat, yaitu posisi laki-laki dan posisi perempuan (Robin Fox:14, dalam Syahrizal, 2012:914). Pada kekerabatan patrilineal posisi laki-laki lebih penting daripada posisi perempuan dan sebaliknya pada kekerabatan matrilineal posisi perempuanlah yang lebih penting, terutama terkait dengan keberlangsungan kekerabatan tersebut.

Beberapa bentuk sistem kekerabatan di dunia adalah unilineal, bilateral, dan sistem keturunan ganda. Sistem kekerabatan matrilineal bersama dengan patrilineal termasuk ke dalam sistem kekerabatan yang menetapkan garis keturunan berdasarkan satu garis atau unilineal. Kalau dalam sistem kekerabatan matrilineal menghitung hubungan kekerabatan melalui perempuan dalam sistem kekerabatan patrilineal menetapkan garis keturunan dihitung menurut garis ayah atau laki-laki. Sistem kekerabatan lainnya adalah sistem kekerabatan non unilineal yaitu bilineal dan bilateral. Sistem kekerabatan bilineal menghitung hubungan kekerabatan melalui laki-laki saja untuk sejumlah hak dan kewajiban tertentu dan melalui perempuan saja untuk sejumlah hak dan kewajiban tertentu. Sedangkan sistem kekerabatan bilateral menghitung hubungan kekerabatan melalui laki-laki maupun perempuan (Koentjaraningrat: 129-130).

Pada sistem keturunan unilineal, baik yang matrilineal maupun yang patrilineal, terdapat tiga prinsip yang bisa dikatakan secara teoritis berlaku universal (Schneider dan Gough dalam Amri Marzali 2000:2) prinsip-prinsip tersebut adalah : 1) wanita bertanggung jawab memelihara anak-anak; 2) pria dewasa mempunyai wewenang terhadap wanita dan anak-anak; dan 3) perkawinan eksogami kelompok merupakan suatu keperluan.

Selanjutnya menurut Marzali (2000) ciri-ciri khas sistem matrilineal adalah sebagai berikut: 1) keturunan ditelusuri melalui garis wanita; 2) anggota kelompok keturunan direkrut melalui garis wanita; 3) pewarisan harta dan suksesi politik disalurkan melalui garis wanita. Ciri-ciri sistem parilineal adalah

\footnotetext{
${ }^{1}$ Penulis adalah dosen tetap jurusan Antropologi FISIP Universitas Andalas, Padang

${ }^{2}$ Penulis adalah dosen tetap jurusan Antropologi FISIP Universitas Andalas, Padang
} 
sebaliknya semuanya berdasarkan garis lakilaki.

Sementara itu Muhammad Rajab (1969:17) menjelaskan sistem matrilineal Minangkabau mempunyai delapan ciri yaitu : 1) keturunan dihitung menurut garis ibu; 2) suku terbentuk menurut garis ibu; 3) tiap orang harus kawin di luar sukunya; 4) pembalasan dendam merupakan kewajiban bagi seluruh suku; 5) kekuasaan di dalam suku, menurut teori terletak di tangan "ibu" tetapi jarang sekali dipergunakannya, sedangkan; 6) yang sebenarnya berkuasa adalah saudara laki-laki ibu;7) perkawinan bersifat matrilokal, yaitu suami mengunjungi rumah istrinya; 8) hak-hak dan pusaka diwariskan oleh mamak kepada kemenakannya, dari saudara laki-laki ibu kepad anak dari saudara perempuan.

Sistem kekerabatan matrilineal terbilang langka karena hanya beberapa suku bangsa di dunia yang mempunyai sistem kekerabatan seperti ini. Heider (1997: 182) menyebutkan beberapa contoh masyarakat matrilineal di dunia seperti masyarakat Navajo dan Hopi di Amerika Utara, beberapa suku bangsa di sub sahara Afrika, beberapa kebudayaan di India khsusnya adalah di selatan negara bagian Kerala dan menurut dia populasi masyarakat matrilineal yang terbesar adalah suku bangsa Minangkabau di Indonesia.

Oleh karena sistem kekerabatan matrilineal termasuk langka dan juga dikaitkan dengan masyarakat Minangkabau yang memegang teguh agama Islam yang lebih bersifat patriarkhi banyak ilmuan dan pemerhati sosial dan budaya yang tertarik untuk menelitinya dan membicarakannya. Seperti Hamka (1984:13), berbicara bahwa adat Minangkabau dapat dilengkapi dengan ajaran Islam tanpa harus mempertentangkannya. Hal ini ditulis karena ramainya orang mengatakan adat Minangkabau yang matrilineal bertentangan dengan Islam tertutama terkait dengan pewarisan. Sejalan dengan Hamka, Amir Syarifuddin (1984) berpendapat bahwa ada kompromi antara adat dan agama. Selanjutnya ada Tsuyoshi Kato (1982) yang bicara tentang perubahan pada siitem kekerabatan Minangkabau. Menurut Kato sebenarnya sejak awal abad ke 20 sudah mulai terjadi perubahan dalam sistem kekerabatan matrilineal. Hal itu ditandai dengan menguatnya ikatan perkawinan antara suami istri dan menguatnya hubungan antara ayah dengan anak. Kemudian, ada juga beberapa penulis yang membicarakan tentang pemegang kekuasaan di Minangkabau di antaranya seperti Rajab (1969), Koentjaraningrat (1983), Kato (1982), dan Heider (1997) mengatakan bahwa dalam sistem matrilineal Minangkabau walaupun garis keturunan berdasarkan perempuan tetapi yang berkuasa adalah laki-laki, laki-laki bertindak sebagai pemimpin kaumnya dan menjadi wakil kaum dalam masyarakat nagari atau masyarakat yang lebih luas. Sedangkan Peggy Reeves Sanday (1998) mempunyai pendapat lain dia menjelaskan bahwa sebenarnya masyarakat Minangkabau matriarkhat karena perempuan mempunyai kekuasaan. Menurut Sanday dalam hubungan sosial posisi perempuan sama dengan "titik pusat dari satu jaring". Perempuan senior diasosiasikan dengan tiang utama dari rumah gadang, dikatakan tiang paling utama karena pertama didirikan. Sanday menjelaskan bahwa matriarkhi dalam masyarakat Minangkabau adalah tentang perempuan sebagai pusat asal usul, dan dasar dari tidak hanya kehidupan tetapi juga tatanan sosial (dalam Syahrizal dan Sri Meiyenti, 2012:917). Tentu jika diurai lebih lanjut masih banyak lagi penulis-penulis lain yang mengangkat tentang tema masyarakat Minangkabau.

Pada kesempatan ini kami juga mengupas tentang masyarakat matrilineal Minangkabau. Topik yang kami angkat adalah "Perubahan Sistem Istilah kekerabatan yang Berpengaruh pada Perubahan Sistem Kekerabatan". Topik ini merupakan bagian dari hasil penelitian kami yang didanai DIKTI dari Skim Hibah Bersaing pada tahun anggaran 2009 dan 2010 yang berjudul "Sistem Kekerabatan Minangkabau Kontemporer: Suatu kajian Perubahan dan Keberlangsungan Sistem Kekerabatan Matrilineal Minangkabau". Penelitian ini dilakukan di dua lokasi yang mewakili daerah darek (dianggap wilayah asli Minangkabau) dan daeah rantau (daerah perluasan wilayah Minangkabau). Di daerah darek penelitian dilakukan di Nagari Sumpur Kabupaten Tanahdatar dan di daerah rantau penelitian dilakukan di Nagari Sungai Asam di Kabupaten Padang Pariaman.

Sebelum mengurai tentang perubahan pada sistem istilah kekerabatan Minangkabau perlu diuraikan dulu seperti apa 
sistem istlah kekerabatan Minangkabau asli. Setelah itu baru dibicarakan tentang perubahannya. Perubahan yang dibicarakan meliputi perubahan sistem istilah kekerabatan dan pengaruhnya pada sistem kekerabatan itu sendiri.

\section{B. Sistem Istilah Kekerabatan Minangkabau Asli}

$\mathrm{S}$ istem istilah kekerabatan mempunyai sangkut paut yang erat dengan sistem kekerabatan dalam masyarakat. Hubungan antara sistem istilah kekerabatan dalam suatu bahasa dengan sistem kekerabatan dari suku bangsa yang mengucapkan itu adalah suatu hal yang mulamula ditemukan oleh LH Morgan. Dalam hal memperhatikan sistem istilah kekerabatan itu Morgan mendapatkan suatu cara untuk mengupas semua sistem kekerabatan dari beribu-ribu suku bangsa di dunia yang satu dengan yang lain berbeda-beda bentuknya. Cara itu berdasarkan gejala kesejajaran yang sering ada antara sistem istilah kekerabatan (system of kinship terminology) dengan sistem kekerabatannya (kinship system) (Koentjaraningrat 1985:133)

$$
\text { L.H Morgan mencontohkan }
$$

perbedaan antara sistem istilah kekerabatan dalam masyarakat Inggris dengan masyarakat Indian Iroquis. Dalam masyarakat Inggris ada perbedaan istilah untuk ayah dan saudara laki-laki ayah. Ayah dalam bahas Iggris disebut dengan father dan paman saudara laki-laki ayah disebut dengan uncle. Dalam masyarakat Indian Iroquis panggilan untuk ayah dan saudara laki-laki ayah sama yaitu hanih (dalam Syahrizal dan Sri Meiyenti, 2012:919). Ini menurut LH Morgan berkaitan dengan sistem kekerabatan dalam hal hak dan kewajiban orang yang terkait dengan ego itu. Dalam masyarakat Inggris hak dan kewajiban ayah berbeda dengan saudara lakilaki ayah terhadap seorang anak (ego), sedangkan dalam masyarakat Iroquis hak dan kewajiban ayah dan saudara laki-laki ayah sama terhadap seorang anak (ego).

Hildred

Geertz

$(1983: 19)$

menguraikan sistem pertalian keluarga Jawa dengan dengan mengalisis sitem terminologi atau sistem istilah kekerabatan dalam masyarakat Jawa tersebut. Menurut Geertz istilah yang digunakan oleh seseorang untuk membeda-bedakan sanak saudaranya merupakan suatu sistem yang tali temali, suatu pola pertalian yang mendasari pandangan tertentu mereka tentang pertalian keluarga. Aspek-aspek penghubung keluarga yang ditegaskan dalam terminologi pertalian keluarga bisa tidak selalu menjadi aspek paling penting dalam arti keadaan pertalian keluarga yang sebenarnya namun tetap mempunyai arti penting tertentu.

Menurut Geertz bentuk dasar sistem terminologi Jawa adalah bilateral dan generasional, bersisi dua dan turun temurun. Artinya bahwa istilah-istilah keluarga tersebut sama, apakah saudara perangkainya ibu ataukah ayah, dan bahwa semua anggota dari setiap generasi digabungkan dengan kata-kata. Semua anggota generasi sendiri, misalnya saudara-saudara ibu dan saudara sepupu, disebut dalam istilah-istilah yang sama atau mirip, semua anggota dari generasi orang tua misalnya ayah ibu, kakak, adik, serta saudara sepupu mereka, disebut dengan sekelompok istilah lainnya yang serupa, semua anggota dari generasi kakek nenek termasuk adik kakak mereka disebut dengan istilah tersendiri, dan lain-lainnya. Hasilnya adalah suatu stratifikasi horizontal atas semua anak saudara tersebut. Setiap orang Jawa melihat dirinya sendiri ada ditengah-tengah tata sebuah jajaran "kakek nenek", "ayah ibu", "kakak adik", anak-anak", dan "cucu-cucu".

Sistem istilah kekerabatan

Minangkabau berbeda dengan sistem istilah kekerabatan Jawa, hal ini dipengaruhi oleh sistem kekerabatan itu sendiri yakni Minangkabau matrilineal dan Jawa bilateral. Sistem kekerabatan bilateral seperti yang disebutkan Geertz bersisi dua tidak membedakan saudara perangkainya ayah atau ibu. Sedangkan sistem istilah kekerabatan Minangkabau berbeda istilah kekerabatan untuk kerabat yang saudara perangkainya ibu sebagian berbeda dengan istilah kekerabatan yang saudara perangkaianya ayah. Ini sejalan dengan teori L.H.Morgan di atas bahwa perbedaan istilah berkaitan dengan peran serta hak dan kewajiban seseorang terhadap ego. Atau merupakan konsekuensi logis dari sistem matrilineal itu sendiri yang merupakan sistem kekerabatan unilineal di mana garis kekerabatan dihitung melalui garis ibu atau perempuan. Artinya ada perbedaan antara kerabat ayah dan kerabat ibu, kerabat ayah 
dianggap berada di luar kelompok kerabatnya sedangkan kerabat ibu adalah termasuk dalam kelompok kerabatnya.

Istilah kekerabatan untuk menyebut saudara laki-laki ayah dan saudara laki-laki ibu dalam istilah kekerabatan Jawa tetap dipanggil pak yang tidak membedakan kerabat ayah dan ibu, kemudian ditentukan oleh tingkatan usia dari ayah atau ibu yang lebih tua dipanggil pak de dan yang lebih muda dipanggil pak lik. Dalam masyarakat Minangkabau saudara laki-laki ayah di panggil bapak atau pak dan saudara laki-laki ibu dipanggil dengan mamak. Saudara perempuan ibu dan saudara perempuan ayah juga disebut dengan istilah yang berbeda.

Dari gambaran garis besar kerangka sistem istilah kekerabatan tersebut poin yang membedakan antara kerabat ayah dan kerabat ibu adalah pada istilah untuk saudara laki-laki ibu dan saudara laki-laki ayah. Kalau saudara laki-laki ibu dipanggil mamak saudara saudara laki-laki ayah dipanggil dengan bapak. Perbedaan istilah ini mengingatkan kita pada analisis LH Morgan tentang perbedaan antara istilah kekerabatan Inggris dan Iroquis yang menjelaksan adanya perbedaan hak dan kewajiban berkaitan dengan perbedaan itu.

Seorang saudara laki-laki ibu secara ideal bertanggung jawab pada ego, dia bertanggung jawab secara ekonomi atau moral terhadap kemenakannya. Hubungan antara mamak dan kemenakan bahwa mamak bertanggung jawab kepada kemenakan secara moral artinya baik buruk perilaku kemenakan itu adalah hasil didikan dari mamaknya. Hal ini terlihat dari ungkapan di masyarakat, apabila ada seorang anak yang berbuat tidak baik, maka yang akan ditanya adalah "kemanakan siapa itu?" bukan ditanyakan "anak siapa itu?". Kemudian, secara ekonomi adalah terjamin atau tidak kehidupan sehari-hari serta biaya pendidikan kemenakan itu adalah tanggung jawab mamak. Sedangkan saudara laki-laki ayah tidak mempunyai hak dan kewajiban yang khusus terhadap ego, interaksi mereka hanya pada suasana-suasana formal bahkan kalau jarak mereka terpisah karena saudara laki-laki ayah ini merantau misalnya mereka tidak akan pernah bertemu dan bahkan bisa tidak saling mengenal. Apabila si ego pergi merantau, maka di rantau yang mereka cari untuk menumpang sementara waktu ia bisa mandiri adalah saudara laki-laki ibunya (mamak), bukan saudara laki-laki ayahnya (bapak).

Perbedaan istilah antara saudara lakilaki ayah dengan saudara laki-laki ibu itu juga menandakan perbedaan hak dan kewajiban antara keduanya terhadap seorang ego. Seorang saudara laki-laki ayah tidak mempunyai tanggung jawab yang sebesar tanggung jawab seorang saudara laki-laki ibu atau mamak terhadap ego. Saudara laki-laki ayah jarang bertemu dengan ego, dia tinggal di rumah istrinya yang mungkin jauh, mereka bertemu hanya pada waktu-waktu tertentu seperti lebaran atau upacara-upacara life cycle. Sedangkan saudara laki-laki ibu lebih sering bertemu dengan ego dia menganggap rumah ego adalah rumah orang tua dan rumah keluarga luas matrilinealnya, hal itu membuat dia sering berkunjung. 
Tabel 1

Sistem Istilah Kekerabatan Minangkabau

\begin{tabular}{|c|c|c|c|}
\hline \multicolumn{4}{|c|}{$\begin{array}{cc}\text { Sdr.Perangkai } & \text { Sdr.Perangkai } \\
\text { Ayah } & \text { lbu }\end{array}$} \\
\hline $\begin{array}{l}\text { Naik Dua ke } \\
\text { Atas }\end{array}$ & $\begin{array}{l}\text { Kakek } \\
\text { Nenek }\end{array}$ & $\begin{array}{l}\text { angku } \\
\text { anduang }\end{array}$ & $\begin{array}{l}\text { Angku } \\
\text { anduang }\end{array}$ \\
\hline $\begin{array}{l}\text { Naik ke Atas } \\
\text { Pertama }\end{array}$ & $\begin{array}{l}\text { kakak laki-laki ayah/ibu } \\
\text { adik laki-laki ayah/ibu } \\
\text { kakak perempuan ayah/ibu } \\
\text { adik perempuan ayah/ibu } \\
\text { istri kakak laki-laki ayah/ibu } \\
\text { istri adik laki-laki ayah/ibu } \\
\text { suami kakak perempuan ayah/ibu } \\
\text { suami adik perempuan ayah/ibu } \\
\text { kakak laki-laki } \\
\text { kakak pr }\end{array}$ & $\begin{array}{l}\text { pak tuo } \\
\text { pak etek } \\
\text { mak tuo } \\
\text { etek } \\
\text { mak tuo } \\
\text { etek } \\
\text { pak tuo } \\
\text { pak etek } \\
\text { uda, tuan, ajo } \\
\text { uni,akak, } \\
\text { uniang,one }\end{array}$ & $\begin{array}{l}\text { mak adang } \\
\text { mak etek } \\
\text { mak tuo } \\
\text { etek } \\
\text { mintuo } \\
\text { etek } \\
\text { pak tuo } \\
\text { pak etek }\end{array}$ \\
\hline \multicolumn{4}{|l|}{ Diri } \\
\hline Saudara muda & & adik & \\
\hline $\begin{array}{ll}\text { Turun } & \mathrm{Ke} \\
\text { bawah } & \\
\text { Pertama } & \end{array}$ & $\begin{array}{l}\text { Anak } \\
\text { anak saudara perempuan } \\
\text { anak sdr laki-laki }\end{array}$ & $\begin{array}{l}\text { anak } \\
\text { kemenakan } \\
\text { anak }\end{array}$ & \\
\hline
\end{tabular}

Perbedaan istilah untuk menyebut saudara laki-laki ayah dan saudara laki-laki ibu juga berakibat pada perbedaan menyebut untuk istri masing-masingnya. Istri dari saudara laki-laki ayah dipanggil amak (mak tuo) untuk yang lebih tua dan etek untuk yang lebih muda. Sedangkan istri saudara laki-laki ibu dipanggil mintuo. Istilah mintuo adalah istilah yang sama untuk menyebut ibu dari istri, mintuo dalam bahasa Indonesia berarti mertua. Istilah ini besar kemungkinan muncul karena terkait dengan perkawinan ideal dalam masyarakat Minangkabau adalah perkawinan cross cousin, perkawinan antara seorang kemenakan dengan anak mamaknya merupakan suatu yang lazim terjadi. Dengan kata lain, istri mamak sudah lazim juga menjadi mertua bagi kemenakannya baik yang laki-laki maupun yang perempuan.

\section{Sistem Kekerabatan Minangkabau Setelah Terjadi Perubahan}

$\mathrm{H}$ al yang menarik istilah kekerabatan yang terjadi sekarang di Minangkabau sudah mulai berubah dipengaruhi oleh bahasa Indonesia atau istilah kekerabatan yang berlaku di kota-kota di Indonesia. Perubahan itu misalnya untuk menyebut ayah dan ibu kalau sebelumnya amak dan apak, sekarang telah berubah menjadi ayah, ibu atau bunda, papa dan mama dan pada akhirakhir ini kecenderungan anak-anak muda yang merupakan keluarga baru yang banyak terpengaruh oleh ajaran Islam ada perubahan untuk memanggil ayah ibu dengan panggilan abah dan umi. Perubahan lainnya, untuk istilah menyebut dan menyapa adik perempuan ibu dan ayah berubah dari etek ke tante. Terjadi juga perubahan dalam istilah untuk mamak, sebagian anak-anak sekarang memanggilnya dengan om. Istilah untuk kakek yaitu ayah dari ibu atau ayah dari ayah sekarang telah berubah dari istilah sebelumnya inyiak atau angku menjadi kakek dan untuk nenek yaitu ibu dari ibu atau ibu dari ayah yang sebelumnya anduang atau uci menjadi nenek. Sebagian keluarga Minangkabau terutama di kota-kota juga menggunakan istilah kekerabatan yang dianggap lebih modern yaitu opa dan oma yang sebenarnya berasal dari istilah kekerabatan orang Belanda.

Perubahan ini menarik untuk dianalisa karena seperti yang disebut oleh LH Morgan bahwa istilah kekerabatan berkaitan dengan sistem kekerabatan itu sendiri. Perubahan panggilan dari mamak menjadi om misalnya apa yang terjadi kelihatannya adalah perubahan itu seiring dengan perubahan

$$
61 \mid \mathrm{P} \text { a g e }
$$


peran mamak itu sendiri. Mamak lebih terikat kepada peran tradisional sebagai pembimbing kemenakan dan juga pembimbing keberlangsungan adat kemudian sekarang perannya semakin berkurang. Om dalam bahasa Indonesia lebih ditujukan pada saudara laki-laki ibu atau ayah, jadi bisa dikatakan bahwa perubahan peran saudara laki-laki ibu juga berhubungan dengan perubahan dari istilah mamak ke istilah om. Perubahan panggilan dari mamak ke om untuk saudara laki-laki ibu membawa konsekuensi terhadap hak dan kewajiban saudara laki-laki ibu terhadap anak-anak saudara perempuannya.

Tabel 2

Perubahan Yang Terjadi pada Sistem istilah kekerabatan Minangkabau

\begin{tabular}{|c|c|c|c|}
\hline & Sdr & $\begin{array}{c}\text { ai } \begin{array}{c}\text { Sdr.Pera } \\
\text { lbu }\end{array} \\
\text { a }\end{array}$ & \\
\hline $\begin{array}{lll}\text { Naik } & \text { Dua } & \text { ke } \\
\text { Atas } & & \\
\end{array}$ & $\begin{array}{l}\text { Kakek } \\
\text { Nenek }\end{array}$ & $\begin{array}{l}\text { Kakek, Opa } \\
\text { Nenek, Oma }\end{array}$ & $\begin{array}{l}\text { Kakek, Opa } \\
\text { Nenek, Oma }\end{array}$ \\
\hline $\begin{array}{ll}\text { Naik ke } & \text { Atas } \\
\text { Pertama } & \end{array}$ & $\begin{array}{l}\text { kakak laki-laki ayah/ibu } \\
\text { adik laki-laki ayah/ibu } \\
\text { kakak perempuan ayah/ibu } \\
\text { adik perempuan ayah/ibu } \\
\text { istri kakak laki-laki ayah/ibu } \\
\text { istri adik laki-laki ayah/ibu } \\
\text { suamikakak perempuan ayah/ibu } \\
\text { suami adik perempuan ayah/ibu } \\
\text { kakak laki-laki } \\
\text { kakak pr }\end{array}$ & $\begin{array}{l}\text { pak tuo } \\
\text { pak etek } \\
\text { mak tuo } \\
\text { tante } \\
\text { mak tuo } \\
\text { tante } \\
\text { pak tuo } \\
\text { pak etek } \\
\text { uda, abang } \\
\text { uni, } \\
\text { kakak,uniang, } \\
\text { one }\end{array}$ & $\begin{array}{l}\text { Om } \\
\text { om } \\
\text { mak tuo } \\
\text { tante } \\
\text { mintuo } \\
\text { tante } \\
\text { om } \\
\text { om }\end{array}$ \\
\hline \multicolumn{4}{|l|}{ Diri } \\
\hline Saudara muda & & Adik & \\
\hline $\begin{array}{l}\text { Turun Ke bawah } \\
\text { Pertama }\end{array}$ & $\begin{array}{l}\text { Anak } \\
\text { anak saudara perempuan } \\
\text { anak sdr laki-laki }\end{array}$ & $\begin{array}{l}\text { Anak } \\
\text { kemenakan } \\
\text { anak }\end{array}$ & \\
\hline
\end{tabular}

Perubahan istilah menyebut dan menyapa untuk ayah, ibu atau paman menjadi fenomena yang menarik dalam percakapan di warung yang melahirkan anekdot-anekdot yang lucu. Bagi sebagian masyarakat penggunaan istilah mama dan papa kurang cocok untuk diterapkan pada keluarga yang bekerja sebagai petani atau orang biasa, istilah tersebut cocok untuk orang-orang berada atau kaya. Menurut mereka kurang pantas orang yang pekerjaan di sawah atau di ladang dipanggil oleh anak-anak mereka dengan papa dan mama. Nanti kalau ada yang bertanya pada anaknya, kemana mamanya atau papanya, anaknya misalnya menjawab mama dan papa ke sawah, hal itu bagi mereka dianggap kurang cocok atau kurang pantas. Anekdot lain mengatakan kalau anaknya memanggil papa,nanti uang jajan untuk anaknya lebih mahal, contoh kalau anak-anak menyebut ayahnya dengan istilah bapak atau apak uang jajannya cukup Rp 1000,- perhari tetapi kalau anak-anak memanggil ayahnya dengan papa tidak bisa uang jajannya Rp 1000,- per hari tetapi harus Rp 5000,- per hari (Syahrizal dan Sri meiyenti, 2012:920).

Tetapi istilah mama dan papa sudah menjadi istilah yang lazim untuk pasangan muda dan yang telah memiliki anak usia remaja sekarang baik di nagari Sumpur maupun di nagari Sungai Asam. Penggunaan istilah ini tidak tergantung kelas sosial dan pekerjaan mereka. Banyak pasangan yang bekerja seb agai petani di Sumpur dan Sungai Asam, atau nelayan di danau Singkarak anakanak mereka menggunakan istilah papa dan mama untuk memanggil orang tuanya. Orangorang yang mencemooh memang kebetulan yang tidak menggunakan istilah tersebut, 
mereka masih tetap menggunakan istilah amak apak, atau sebagian ayah dan ibu, istilah ayah dan ibu dianggap lebih netral.

Perubahan penggunaan istilah ini bisa diartikan indikasi perubahan yang terjadi dalam sistem kekerabatan itu sendiri. Semakin melemahnya keluarga luas dan menguatnya keluarga inti. Perubahan dari istilah mamak menjadi om bisa menandakan perubahan dari peran mamak tradisional ke peran saudara laki-laki ibu yang tidak terlalu terikat dengan nilai-nilai tradisional lagi.

Menurut salah seorang mamak $d i$ Sumpur kelihatannya memang seperti itu, Azwar seorang laki-laki yang bekerja sebagai PNS di kota Padang dan sekali-sekali pulang kampung menceritakan hal seperti itu. Dia memiliki anak-anak dari saudara perempuannya yang masih tinggal di kampung. Anak-anak dari saudara perempuannya itu memanggil dia dengan panggilan om. Bagi dia panggilan tersebut tidak masalah dan panggilan om tersebut membuat dia merasa lebih dekat dengan kemenakannnya. Hubungan dengan kemenakannya lebih bersifat bersahabat mesra dan bersenda gurau. Berbeda dengan hubungan mamak kemenakan masa lampau yang lebih bersifat formal dan kaku. Dia sering bercanda kalau bertemu dengan kemenakannya saat pulang kampung (Syahrizal dan Sri Meiyenti, 2012:921).

Ada perbedaan sedikit dalam istilah kekerabatan antara darek dan rantau di nagari Sungai Asam yang mewakili daerah rantau panggilan untuk kakak laki-laki adalah ajo. Sedangkan dalam masyarakat Minangkabau lainnya panggilan untuk kakak laki-laki adalah uwan atau uda. Demikian juga dengan panggilan untuk kakak perempuan di Sungai Asam panggilannya uniang dan di Sumpur panggilannya uni. Istilah-istilah ini juga sudah mengalami perubahan karena pengaruh kehidupan kota. Istilah untuk ajo atau uda untuk kakak laki-lakinya sebagian anak-anak berubah memakai istilah abang. Sedangkan istilah uniang dan uni untuk kakak perempuan sebagian anak menggantikannya dengan kakak (Syahrizal dan Sri meiyenti, 2012:921).

Perubahan yang terjadi dalam sistem istilah kekerabatan pada untuk sebagian masyarakat Minangkabau kelihatannya karena adanya keinginan untuk dikatakan lebih modern atau tidak kampungan. Selain itu, perubahan juga terjadi karena pengaruh televisi dan banyaknya orang yang pulang dan pergi dari rantau. Mereka mengadopsi sistem istilah kekerabatan yang umumnya berlaku di kota-kota besar di Indonesia dan bahkan luar negri. Sebagian orang Minangkabau di perkotaan - tetapi tidak ditemukan di lokasi penelitian - juga menggunakan istilah papi dan mami untuk menyebut dan menyapa ayah dan ibunya. Kemudian juga ada pengaruh dari agama Islam sendiri yang notabene menggunakan istilah Arab sebagian masyarakat juga menggunakan istilah dari Arab tersebut yaitu buya, abi untuk ayah dan umi untuk ibu. Biasanya digunakan oleh keluarga yang berasal dari kalangan pesantren atau madrasah kalau seorang laki-laki seorang ustadz atau guru agama anak-anak memanggil buya pada dia dan memanggil umi pada istrinya.

\section{Kesimpulan}

$\mathrm{P}$ erubahan sistem istilah kekerabatan ini dapat disimpulkan memang berhubungan dengan perubahan sistem kekerabatan itu sendiri. Semakin menguatnya keluarga inti yang dipengaruhi oleh banyak faktor mengakibatkan berkurangnya peran mamak dan menguatnya peran ayah. Mamak tidak lagi harus merupakan orang yang bertanggung jawab terhadap kemenakannya sehingga kalau istilah menyebut untuk mamak berubah menjadi om bukan masalah. Karena om adalah istilah netral yang dipakai secara nasional bukan hanya oleh orang Minangkabau tetapi juga dipakai oleh sukusukubangsa lain di Indonesia. Hubungan antara kemenakan dengan saudara laki-laki ibu dengan panggilan om menjadikan hubungan mereka tidak sakral lagi. Hubungan mereka mungkin lebih akrab, bisa saling bercanda dan tidak kaku lagi. Hanya saja kadang-kadang karena terlalu akrab menyebabkan wibawa seorang laki-laki sebagai mamak juga memudar di hadapan kemenakannya.

Perubahan ini lebih lanjut juga berakibat perubahan fungsi dan peran mamak sebagai penjaga moral dan penanggung jawab ekonomi kemenakan. Hubungan mamak dan kemenakan menjadi 
hubungan yang bersifat informal dari pada sebelumnya bersifat formal di mana mamak lebih disegani. Tanggung jawab sebagai penjaga moral dan ekonomi anak-anak atau seorang ego sudah dipegang sepenuhnya oleh seorang ayah.

\section{E. Ucapan Terima Kasih}

$\mathrm{K}$ ami sebagai peneliti mengucapkan terima kasih kepada Direktorat Pembinaan Penelitian dan Pengabdian kepada Masyarakat (DP2M), Direktorat Jenderal Pendidikan Tinggi yang telah bersedia membiayai penelitian ini. Ucapan terima kasih juga dipersembahkan kepada Lembaga Penelitian Universitas Andalas yang telah banyak membantu terlaksananya penelitian ini.

\section{Daftar Pustaka}

Amir, M.S. 2001. Adat Minangkabau. Pola dan Tujuan Hidup Orang Minangkabau. PT. Mutiara Sumber Widya. Jakarta.

Bahar, Saafroedin dan M. Zulfan Tadjoedin, 2004. Masih Ada Harapan, Posisi Sebuah Etnik Minoritas dalam Hidup Berbangsa dan Bernegara. Yayasan Sepulug Agustus, Jakarta.

Fox, Robin, 1966. Kinship and Marriage, Penguin Books Ltd. Harmondsworth, England.

Geertz, Hildred, 1982. Keluarga Jawa, Grafiti Pers. Jakarta

Heider, Karl G. 1996. Seeing Anthropology, Cultural Anthropology Through Film, Allyn and Bacon. Boston.

---------, 1991. Landscapes of Emotion, Mapping Three Cultures of Emotion in Indonesia, Cambridge University Press. New York. Ihromi, T.O, (ed).1990. Pokok-Poko Antropologi Budaya, Gramedia, Jakarta.

Koentjaraningrat, 1985. Beberapa Pokok Anropologi Sosial, Dian Rakyat. Jakarta

Marzali, Amri, 2000. "Dapatkah Sistem Matrilineal Bertahan di Kota Metropolitan" dalam Antropologi Indonesia, Th XXIV, NO. 61 Jan - Apr.

Meiyenti dan Syahrizal. 2005. Gerakan perempuan dan keterlibatan Perempuan dalam Pembangunan nagari di Era Kembali ke Nagari. Laporan Penelitian. Kajian Wanita. Dikti.

Naim, Mochtar, 1984. Merantau Pola Mingrasi Suku Minangkabau, Gadjah Mada University Press, Yogyakarta.

Navis, A.A. 1984. Alam Terkembang Jadi Guru. Adat dan Kebudayaan Minangkabau, Grafiti Pers. Jakarta.

Kato, Tsuyoshi, 1982. Matriliny and Migration, Evolving Minangkabau Traditions in Indonesia, Cornell University Press, Ithaca and London.

1989. Nasab Ibu dan Merantau, Tradisi Minangkabau yang Berketerusan di Indonesia. Dewan Bahasa dan Pustaka Kementrian Pendidikan Malaysia. Kuala Lumpur. Malaysia

Radjab, Muhammad. 1969. Sistem Kekerabatan di Minangkabau. Center for Minangkabau Studies. Padang.

Sanday, Peggy Reeves. 1998. Matriarchy as a Sociocultural Form ( Paper Presented at The $16^{\text {th }}$ Congress of The Indo-Pacific Prehistory Association, Melaka, Malaysia, 1-7 July, 1998). An Old Debate in a New Light.

Sairin, Syafri. 1995. Demokrasi dalam Perspektif Kebudayaan Minangkabau, dalam Humaniora No. 1. Fakultas Sasara Universitas Gadjah mada. Yogyakarta.

Syahrizal dan Sri Meiyenti, 2012. Sistem Kekerabatan Minangkabau Kontemporer: Suatu Kajian Perubahan dan Keberlangsungan Sistem Kekerabatan Matrilineal Minangkabau. Prosiding: International Conference on Indonesian Studies ISSN 2087-0019. Unity, Diversity and Future, Fakultas IImu Pengetahuan Budaya Universitas Indonesia. Bali, 9-10 Februari 2012. 